\title{
Idiopathic, acquired, localised and transient trichomegaly
}

\author{
Emma Samia-Aly 두, Faye Mellington
}

Birmingham and Midland Eye Centre, Sandwell and West Birmingham Hospitals NHS Trust, Birmingham, UK

\section{Correspondence to} Emma Samia-Aly; emmasamiaaly@gmail.com

Accepted 5 March 2021

\section{DESCRIPTION}

A 34-year-old Asian man presented with a 1-month history of discomfort of the left eye. On examination, he was noted to have a localised area of long curly lashes in the middle third of the left upper eyelid (figure 1A). He had good visual acuity despite having keratoconus, treated with hard lenses. $\mathrm{He}$ had no other medical, ocular, traumatic or surgical history and was not on any systemic or topical medication, including prostaglandins; a common cause. ${ }^{1}$ Our patient opted for initial monitoring instead of biopsy and 2 months later, these lash changes and symptoms had spontaneously improved (figure 1B).

Trichomegaly is the increased length, curling, pigmentation or thickness of eyelashes. ${ }^{2}$ It is a subdivision of hypertrichosis, which can often be idiopathic in nature such as following repetitive trauma, friction, inflammation or surgical scar sites. ${ }^{3}$ On the other hand, trichomegaly is almost always associated with a cause whether it is congenital, acquired or drug induced. ${ }^{4}$ Acquired causes include anorexia, atopic dermatitis, hypothyroidism, systemic lupus erythematosus, HIV infection, pregnancy and malignancy such as metastatic renal adenocarcinoma. ${ }^{4}$ Prostaglandins, commonly used in glaucoma treatment, are the most common drug-induced cause and result in a characteristic

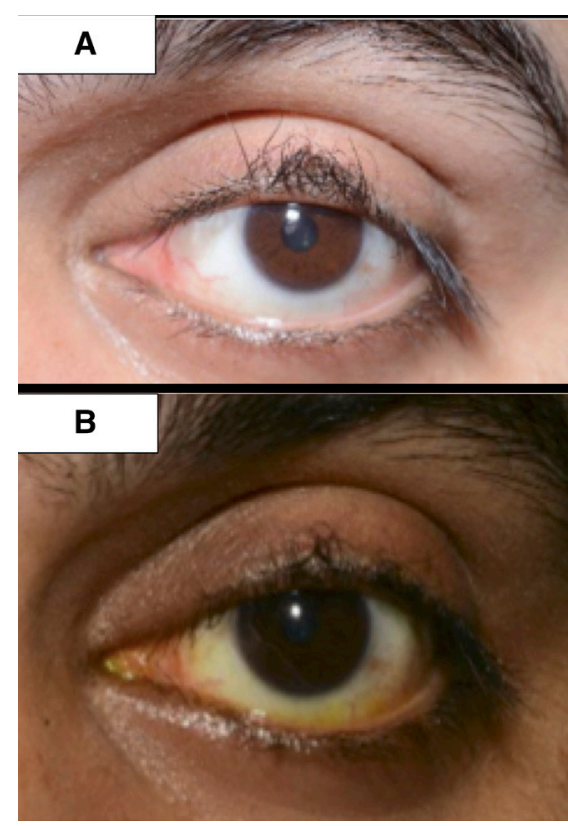

Figure 1 (A) The localised trichomegaly seen at presentation compared with the spontaneously resolving lash changes seen 2 months later in (B). lash appearance. ${ }^{1}$ However, other drugs such as corticosteroids, penicillamine, phenytoin, topiramate, epidermal growth factor receptor inhibitors, ciclosporin and tacrolimus have been associated. ${ }^{4}$ Therapeutic options therefore involve targeting the cause, however trimming, epilation and surgery can help those that are symptomatic and observation for those asymptomatic. Our case highlights the importance of a good history, as well as conservative treatment being a perfectly reasonable initial treatment option. Although our patient's use of hard lenses may be hypothesised as a cause for localised trauma and therefore induce trichomegaly, it does not explain why this occurred after over 10 years of contact lens wear with spontaneous improvement with no change of habit. We present a rare case of an idiopathic, acquired and localised trichomegaly which seems to be transient in nature.

\section{Learning points}

- Idiopathic trichomegaly is rare, with no cases in the literature discussing a transient selfresolving form.

- Conservative management is a reasonable initial approach in unusual cases of trichomegaly.

- Importance of a thorough history to ascertain and rule out causes, particularly those that are serious in nature

Contributors ES-A has contributed to the conception and design of the study, acquisition of data, drafting and editing the article for final approval for submission. FM has contributed to the conception and design of the study, revising the content and approving the final version.

Funding The authors have not declared a specific grant for this research from any funding agency in the public, commercial or not-for-profit sectors.

Competing interests None declared.

Patient consent for publication Not required.

Provenance and peer review Not commissioned; externally peer reviewed.

ORCID iD

Emma Samia-Aly http://orcid.org/0000-0003-4877-9239

\section{REFERENCES}

1 Hempstead N, Hempstead RW. Unilateral trichomegaly induced by bimatoprost ophthalmic solution. J Drugs Dermatol 2004;3:571-2.

2 Kaur S, Mahajan B. Eyelash trichomegaly. Indian I Dermatol 2015;60:378-80.

3 InSaleh D, Yarrarapu SNS, Cook C. Hypertrichosis. Treasure Island, FL: StatPearls Publishing, 2020.

4 Paul LJ, Cohen PR, Kurzrock R. Eyelash trichomegaly: review of congenital, acquired, and drug-associated etiologies for elongation of the eyelashes. Int J Dermatol 2012;51:631-46. 
Copyright 2021 BMJ Publishing Group. All rights reserved. For permission to reuse any of this content visit https://www.bmj.com/company/products-services/rights-and-licensing/permissions/

BMJ Case Report Fellows may re-use this article for personal use and teaching without any further permission

Become a Fellow of BMJ Case Reports today and you can:

- Submit as many cases as you like

Enjoy fast sympathetic peer review and rapid publication of accepted articles

Access all the published articles

Re-use any of the published material for personal use and teaching without further permission

Customer Service

If you have any further queries about your subscription, please contact our customer services team on +44 (0) 2071111105 or via email at support@bmj.com.

Visit casereports.bmj.com for more articles like this and to become a Fellow 